\title{
The Effect of Human Resource Management Practices on Organizational Performance Moderated by Religiosity
}

\author{
Nabilah Choerunisa ${ }^{1}$, Evony Silvino Violita ${ }^{2}$ \\ \{nabnisa@gmail.com¹, evony.silvino@gmail.com ${ }^{2}$ \}
}

Depok, Indonesia, Faculty of Economic and Business Universitas Indonesia ${ }^{1,2}$,

\begin{abstract}
Indonesia is a country with the largest Muslim population with $87.2 \%$ of the total population. There is a possibility that Islamic values can affect the work environment. This study examined whether human resource management practices consist of selection, training, evaluation, employee participation and compensation affect organizational performance. The role religiosity in moderating the relationship is also examined. Using five non-profit Islamic institutions as the sample, this study shows that the practice of human resource management influences organizational performance, while religiosity is not proven to moderate the relationship It tells that organizational performance is still driven by the selection process, training, evaluation, employee participation and compensation to achieve good organizational performance and that the employees are more motivated by the human resources management process. it implies that employees do not really influence by their religion understanding and do not integrate their religion into their workplace.
\end{abstract}

Keywords: nonprofit organization, human resource management practices, organizational performance, religiosity.

\section{Introduction}

Human resources (HR) is an important element for the company, especially in labor-intensive organizations. HR must be managed in such a way that employees have stable and improved performance that will ultimately affect the performance of the organization. With the establishment of an efficient system, HR can be a strategic asset for the company because the system is not easily imitated or replaced [1]. A good HR management (HRM) practice is required to ensure that a company or organization is able to achieve success through its human resources [2]. HRM practices developed from Western countries are widely adopted by other countries because of their universal nature. But the value embodied in human resource practice consist of the thought from the West, while every region of the world has the value in the form of culture or religion. Values are a set of principles that humans believes and religions can have a strong influence on their followers to follow values based on their teachings. With the largest Muslim population in Indonesia, it is possible that Islamic values can affect the work environment in the form of regulations applied to employees [3].

Although the current Islamic economy is developing in Muslim-majority countries such as Indonesia and Malaysia, the focus of much research is still limited to the financial and banking sectors [4]. Though Islamic economics is not limited to the financial sector because Islam is a perfect religion whose teachings cover all aspects of life.

With regard to human resources practices in Indonesia, there have not been many studies examining the influence of Islamic principles and their impact on human resource management practices. In contrast to other Muslim majority countries that have conducted research related to the principle of Islam and its relation to the 
practice of human resource management. Therefore this study attempts to eliminate the research gap in Islamic economic literature.

By examining five nonprofit organization, this study finds that the practice of human resource management influences organizational performance, while religiosity is not proven to moderate the relationship. It tells that organizational performance is still driven by the selection process, training, evaluation, employee participation and compensation to achieve good organizational performance and that the employees are more motivated by the human resources management process.

This paper discuss the background in part one and followed by the literature review in part two. Research method is discussed in in chapter three and result and analysis are discussed in part four and five respectively.

\section{Literature Review}

\subsection{Organization Performance and Human Resources}

Performance can be defined as an outcome or target achievement. The performance of an organization can be seen from the extent to which the organization has reached a predetermined target as a result of the management of resources available. Basically, organizational performance is a multidimensional concept, but it can be measured in two ways: financial and nonfinancial performance [5]. The financial dimension can be measured through profit, return on asset, return on investment, sales level and others, while the nonfinancial dimension can be measured through customer satisfaction, service quality, employee turnover and others. In Islam, organizational performance can be divided into two namely the achievement of organizational objectives and achievement of the provisions of God [5]. In fulfilling the provisions of Allah a Muslim should pay attention to his achievement in working in a good way and according to Islamic teachings because a Muslim is taught that all deeds that have been done in the world will be accounted for in the hereafter.

Human resource practices can affect the performance of the organization in two ways, directly by improving the ability and quality of employees as well as by indirectly by increasing employee motivation [1]. Direct effect is gained from a process of good employee selection and training, while indirect influence is through increased employee motivation, one of which can be done by giving incentives. Ulrich (1997) argues that the use of good human resources will be correlated with high business performance.

Amin, et al (2014) finds the relationship between recruitment, training, performance evaluation, career plans, employee participation, compensation and job definition having a significant influence on the performance of universities in Malaysia. Further research by Katou (2008) finds HRM affects organizational performance and that human resource practices mediating partially the relationship. Study by Vanhala \& Tuomi (2006) suggests that the relationship between human resource practices and employee well-being is weak, while human resource practices can be good predictor variables for organizational performance.

\subsection{Human Resources Practice}

The practice of HRM in organizations is in various forms. It can consist of staffing, training, performance and management empowerment (Moideenkutty et al., 2011), selection, training, performance appraisal, career plans, job definitions and compensation (Amin et al., 2014), training, compensation and participation ([1], [11], selection, compensation, training and Recruitmentrare [12]. This study uses five dimensions, selection, training, compensation, evaluation and participation to measure HRM practice. Selection or recruitment is a process to attract candidates with the qualifications required to enroll in a particular position of an organization [13]. The selection process should look for candidates who have the required competencies regardless of anything other than that such as friendship. Then honesty must be applied both sides. Employee participation is an opportunity for employees to participate in managerial decisions by exchanging information and ideas [7]. Employee participation contributes to team building and employee sense of belonging to the institution, encouraging employees to contribute more to institutional success and functioning to avoid making decisions [14]. In Islam there is a term shura (negotiation), it is a decision-making with the parties related to the decision to be taken. In shura the decision will be discussed by the parties involved so there is no one-sided decision making. In the organization manager is expected to discuss with colleagues in the decision-making process [15]

Manager can use compensation to motivate employeessuch as salary and bonus systems to attract, retain and motivate employees to achieve organizational goals [13]. Islam teaches to reward employees according to 
the qualifications, knowledge, experience, capability and workload of employees [5]. the amount of compensation given should be fair and without discrimination.

According to Pynes (2009) training is one of the essential activities to have effective HRM. Training should be seen as a sustainable necessity because organizations will always be faced with new problems, new employee arrivals, changes in technology and changes in the socio-cultural environment. In Islam, the learner will be raised by God. Training in the Islamic side focuses on the importance of knowledge on the principles of Islam, the selection of types and training techniques [5].

Based on the expalantion above, the hypotheses is that human resource management practices have a positive effect on organizational performance. HRM practice covers selection, training, compensation, evaluation and participation. As the Islamic principles are embedded with each person that influence every aspect in man's life, it is expected that religiosity can moderate the relationship as the second hypotheses.

\section{Research Method}

This study uses primary data by distributing questionnaires to permanent employees of five philanthropy organizations in Jakarta and Bandung as among biggest city in Indonesia. The is processed by using Structural Equation Modeling Partial Least Square. Here is the model of the research:

$$
\mathrm{Y}=\mathrm{const}+\mathrm{HRM}+\mathrm{HRM} \times \mathrm{R}+\mathcal{E}
$$

Where HRM is the Human Resouces Practice of the organization and $\mathrm{R}$ is the religiosity of the respondents.

Questionnaire of 6 Likert scale consists of four independent variables conponent of HRM practice, Religiosity as the moderating variable and the dependent variable. Organization performance is measured through the perception of the employee about the quality and quantituy of services provided by the organization upon the donation collection and distribution. Questionnaire in full text can be obtained directly by emailing the corresponding author.

\section{Result}

Table 1 shows the t-value of the variables teseted after a boostrap process. the result says that only hypotheses one (human resource management practices: of selection, training, participation, performance evaluation and compensation) that have a positive effect on organizational performance. Meanwhile, religiosity is not found to moderate the relationship.

Tabel 1. Hypothesis testing

\begin{tabular}{ccc}
\hline Hypothesis & Outer loading & T Value \\
\hline H1 & 0.733 & $12.868^{*}$ \\
\hline H2 & 0.126 & $1.289^{* *}$ \\
\hline
\end{tabular}

*Significant at 0.05 one tailed **not significan at 0.05 one tailed

\section{Discussion}

In this research, human resource management practices have positive and significant influence on organizational performance. In table 3 , the measurement of hypothesis one yields t value of 12,868 , the value is above the value of 1645 so this study proves that human resources management practices consisting of selection, training, compensation, performance evaluation and employee participation proved to have a significant effect on performance nonprofit organization performance. The results of this research are different from the results of Rana \& Malik (2014). Then the second result in this study Islamic principles do not have a positive and significant relationship in influencing the relationship between HR practices and organizational performance. In table 3 the measurement of the two hypotheses yields a t value of 1,289 , the value is below the value of 1.645 so this study does not prove hypothesis two. The results are in accordance with research conducted by Branine \& Pollard (2010) which states that there is a gap between the theory of Islamic management and practices that occured in the Arab countries. Research conducted by Khan \& Rasheed (2015) stated that Islamic work ethic does not moderate management practice relations in the form of compensation, 
training and evaluation of employees with the success of a work project. Then the results of this study is the same as research conducted by Azmi (2015) where recruitment and compensation process conducted with Islamic principle does not produce a significant relationship with organizational performance. This can happen because a Muslim can understand the teachings of Islam, but in the work environment it is not necessarily applied. In addition, other research proves that in Islamic countries culture can have greater influence than religion[4], [17]. The study conducted by Hofstede (2006) states that culture can be a moderator of organizational performance. An organization that is in the Muslim area or claiming its Islamic system is not a strong reason to prove the practice based on Islamic teachings has been implemented [4].

Research conducted by Tayeb (1997) which discusses the influence of Islamic values on the practice of human resource management in the workplace states that there are several reasons to explain the inconsistencies between the expected practiced of Islamic principle with the reality that occurred. The Islamic teachings brought through the Messenger of Allah have an open character for interpretation and the work environment is a fertile place for the interpretation. The influence of Islamic principles on human resource management practices can not be separated from the influence of other factors not explained in this study such as political, social and economic factors that shape the overall human character. Then Tayeb also argues that many local social characteristics are included in the "Islamic" behavior, so there is variation among Islamic countries in interpreting Islamic values and principles.

For nonprofit managerial parties need to be aware that employees' perceptions of human resource management practices consisting of selection, training, compensation, evaluation and employee participation are among the most important to be considered as they have a significant effect on organizational performance.

Although the principle of Islam is not proved to moderate the relationship between human resource management practices, it does not mean that the working environment in accordance with Islamic principles or the implementation of Islamic activities in the office environment has no effect at all. This can happen because employees consider the work environment and Islamic activities in the workplace is only limited to formality. In addition, awareness about implementing the values contained in the Quran relating to the work environment needs to be more reviewed and improved.

Suggestions for further research the study should be conducted not limited to non-profit institutions that ruled their programs based on Islamic values so that Islamic principle variables can be replaced by the religiosity in general, so that respondents are more heterogeneous. Second, adding other endogenous variables besides organizational performance so that the influence of Islamic principles can be known relation with other variables such as career path and organizational commitment. next, comparing the different types of institutions and religions to see how the influence of religiosity in other institutions and the degree of religiosity. The measurement of organizational performance is measured by non-perceptual measurement methods. For example, the measurement of financial ratios and performance of charity. Increasing and prioritizing respondents from the managerial and employees who have long working time over five years. Incorporating an indicator of the principle of Islam derived from the Qur'an, as work is part of worship, intends to work for the reward of God equal to the reward of a mujahid and not forget that his work will be accountable to God in the Hereafter.

\section{References}

[1] G. H. Harel and S. S. Tzafrir, "The effect of human resource management practices on the perceptions of organizational and market performance of the firm," Hum. Resour. Manage., vol. 38, no. 3, pp. 185200, 1999.

[2] M. Amstrong, A Handbook of Human Resource Management Practice, 10th ed. 2008.

[3] F. Fesharaki and S. Sehhat, "Islamic human resource management (iHRM) enhancing organizational justice and employees' commitment," J. Islam. Mark., vol. 9, no. 1, pp. 204-218, 2018.

[4] M. H. Rana and M. S. Malik, "International Journal of Islamic and Middle Eastern Finance and Management Article information :," Int. J. Islam. Middle East. Financ. Manag., vol. 10, no. 2, pp. 186207, 2014.

[5] I. A. G. Azmi, "Islamic human resource practices and organizational performance: Some findings in a developing country," J. Islam. Account. Bus. Res., vol. 6, no. 1, 2015.

[6] D. Ulrich, "Measuring human resources: An overview of practice and a prescription for results," Human Resource Management, vol. 36, no. 3. pp. 303-320, 1997.

[7] M. Amin, W. Khairuzzaman Wan Ismail, S. Zaleha Abdul Rasid, and R. Daverson Andrew Selemani, 
"The impact of human resource management practices on performance," TQM J., vol. 26, no. 2, pp. 125-142, 2014.

[8] A. A. Katou, "Measuring the impact of HRM on organizational performance," J. Ind. Eng. Manag. vol. 1, no. 2, pp. 119-142, 2008.

[9] S. Vanhala and K. Tuomi, "HRM, company performance and employee well-being," 2006

[10] U. Moideenkutty, A. Al-Lamki, and Y. Sree Rama Murthy, "HRM practices and organizational performance in Oman," Pers. Rev., vol. 40, no. 2, pp. 239-251, 2011.

[11] J. T. Delaney and Mark A. Huselid, "The Impact of Human Resource Management Practices on Perceptions of Organizational Performance Author ( s ): John T . Delaney and Mark A . Huselid Published by: Academy of Management Stable URL: http://www.jstor.org/stable/256718 REFERENCES Linked refer," Acad. Manag. J., vol. 39, no. 4, pp. 949-969, 1996.

[12] P. M. Rosenzweig and N. Nohria, "Influences on Human Resource Management Practices in Multinational Corporations," J. Int. Bus. Stud., vol. 25, no. 2, pp. 229-251, 1994.

[13] J. E. Pynes, Human resources management for public and nonprofit organizations: a strategic approach. 2009.

[14] M. S. B. A. Razimi, M. M. Noor, and N. M. Daud, "The concept of dimension in human resource management from Islamic management perspective," Middle - East J. Sci. Res., vol. 20, no. 9, pp. 1175-1182, 2014.

[15] M. Branine and D. Pollard, "Human resource management with Islamic management principles: A dialectic for a reverse diffusion in management," Pers. Rev., vol. 39, no. 6, pp. 712-727, 2010.

[16] A. S. Khan and F. Rasheed, "Human resource management practices and project success, a moderating role of Islamic Work Ethics in Pakistani project-based organizations," Int. J. Proj. Manag., vol. 33, no. 2, pp. 435-445, 2015.

[17] C. Sedikides and J. E. Gebauer, "Religiosity as self-enhancement: A meta-analysis of the relation between socially desirable responding and religiosity," Personal. Soc. Psychol. Rev., vol. 14, no. 1, pp. 17-36, 2010.

[18] G. Hofstede, "What did GLOBE really measure? Researchers' minds versus respondents' minds," Journal of International Business Studies, vol. 37, no. 6. pp. 882-896, 2006.

[19] M. Tayeb, "Islamic revival in Asia and human resource management," Empl. Relations, vol. 19, no. 4, pp. 352-364, 1997. 